\title{
Mega-giant coronary aneurysm: antithrombotic therapy is an option
}

${ }^{1}$ Department of Cardiology, Lariboisière Hospital, Paris, Îlede-France, France

${ }^{2}$ Department of Radiology, Lariboisière Hospital, Paris, îlede-France, France

\section{Correspondence to} Patrick Henry, patrick.henry@aphp.fr

Accepted 30 July 2017

\section{(1) \\ CrossMark}

To cite: Spagnoli V, Dautry R, Dillinger JG, et al. BMJ Case Rep Published Online First: [please include Day Month Year]. doi:10.1136/bcr-2017 220950

\section{Vincent Spagnoli, ${ }^{1}$ Raphael Dautry, ${ }^{2}$ Jean Guillaume Dillinger, ${ }^{1}$ Patrick Henry ${ }^{1}$}

A 69-year-old man with a history of hypercholesterolaemia presented to the emergency department with atypical chest pain. Physical examination was normal and ECG showed no evidence of ischaemic changes. Laboratory studies were notable for a D-dimer level of $1842 \mathrm{ng} / \mathrm{mL}$ (reference value $<500 \mathrm{ng} / \mathrm{mL}$ ) and the troponin I level was normal.

Chest X-ray was normal. Chest CT angiography ruled out a pulmonary embolism but showed a giant and extensive aneurysm of the right coronary artery (RCA) up to $45 \mathrm{~mm}$ in diameter with a partly thrombosed lumen and evidence of right ventricle compression on four-chamber view (figures 1 and 2). The volume of the aorta and the RCA appeared similar (figure 3). Doppler echocardiography did not demonstrate right or left heart haemodynamic abnormalities.

Diagnostic coronary angiography showed atheroma and ectasia on the left descending coronary artery and the circumflex. Linked to the very large lumen, the cannulation of the RCA was difficult and the coronary flow appeared slow and very turbulent (figure 4).

Symptoms at presentation resolved and cardiac MRI showed no evidence of myocardial infarction. There were no other aneurysm locations, especially in cerebral arteries or descending aorta.

Complications of coronary aneurysm include compression, rupture, embolisation or thrombosis, and treatment is not consensual. ${ }^{12}$ Due to these

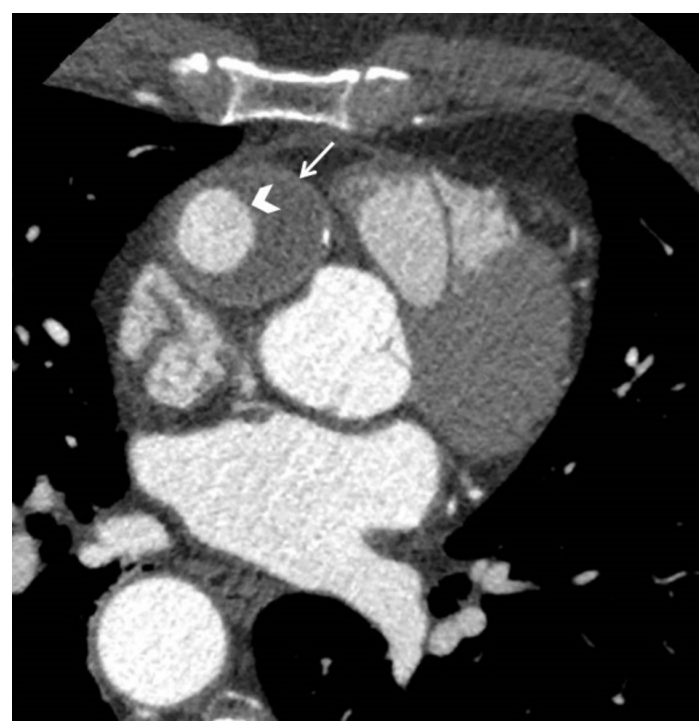

Figure 1 Coronary CT angiography in four-chamber view, evidence of external diameter with arrow and coronary lumen with head arrow.

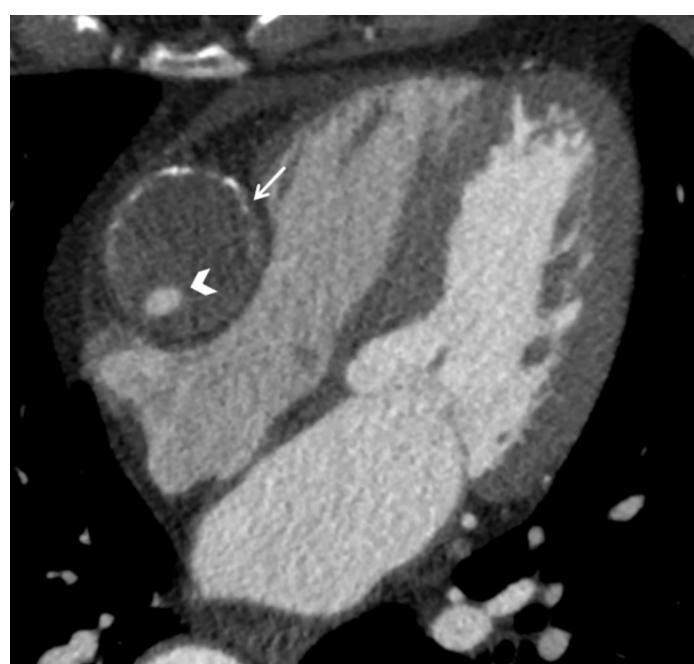

Figure 2 Coronary CT angiography in four-chamber view showing right ventricule compression; evidence of external diameter with arrow and coronary lumen with head arrow.

risks, an interventional approach with surgery or percutaneous coronary intervention was considered but was refused by the patient.

Because of persistent elevation of D-dimer at 1 month $(1590 \mathrm{ng} / \mathrm{mL})$, an evidence of coagulation activation process probably related to the aneurysm, oral anticoagulation, rather than antiplatelet therapy, could represent the antithrombotic therapy of choice in such cases and was prescribed to the patient. Ten months after the diagnosis and



Figure 3 Volume rendering reconstruction of the heart, aorta and the right coronary aneurysm; coronary lumen appears in red. 


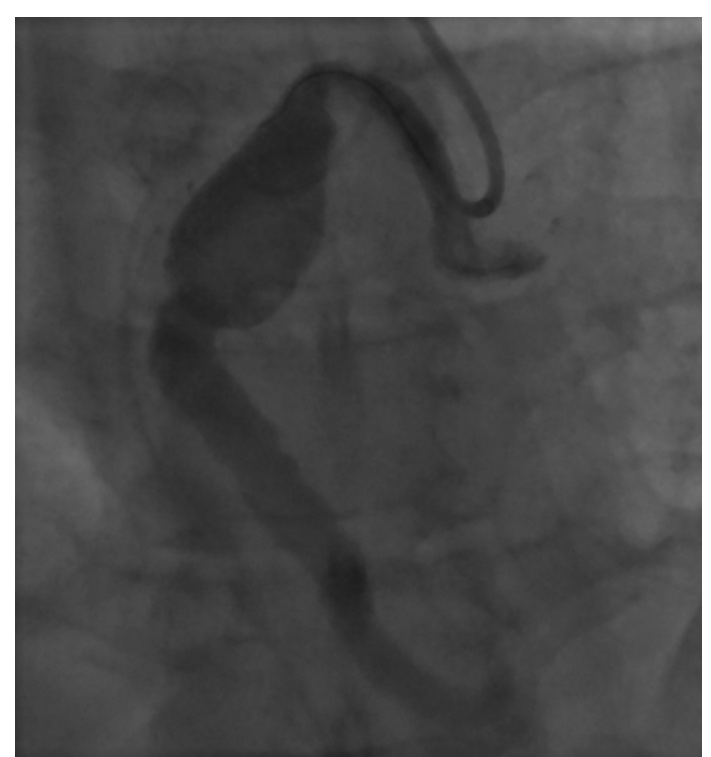

Figure 4 Coronary angiography of the right coronary artery with slow and turbulent flow.

initiation of medical therapy, the patient was asymptomatic and did not experience complication.

\section{Learning points}

- There are no data reported in the literature regarding treatment and indication of surgical or percutaneous management for such aneurysms.

- Medical treatment could be considered in such case.

- No comparison between medical therapy and interventional approach has been made.

- There are no data regarding the best medical therapy (antiplatelet vs anticoagulation therapy).

Contributors VS, JGD, RD and PH contributed to the planning, conduct and report of the work describe in this article. VS and PH are responsible for the overall content.

Competing interests None declared.

Patient consent Obtained.

Provenance and peer review Not commissioned; externally peer reviewed.

(c) BMJ Publishing Group Ltd (unless otherwise stated in the text of the article) 2017. All rights reserved. No commercial use is permitted unless otherwise expressly granted.

\section{REFERENCES}

1 Al Attar N, Sablayrolles JL, Nataf P. Giant atherosclerotic aneurysm of the left anterior descending artery. J Thorac Cardiovasc Surg 2003;126:888-90.

2 Cereda AF, Tiberti G, Pera IG, et al. A Giant Coronary Artery Aneurysm Treated Using Multiple Overlapping Covered Stents. JACC Cardiovasc Interv 2017:10:e127-8.

Copyright 2017 BMJ Publishing Group. All rights reserved. For permission to reuse any of this content visit

http://group.bmj.com/group/rights-licensing/permissions.

BMJ Case Report Fellows may re-use this article for personal use and teaching without any further permission.

Become a Fellow of BMJ Case Reports today and you can:

- Submit as many cases as you like

- Enjoy fast sympathetic peer review and rapid publication of accepted articles

- Access all the published articles

Re-use any of the published material for personal use and teaching without further permission

For information on Institutional Fellowships contact consortiasales@bmjgroup.com

Visit casereports.bmj.com for more articles like this and to become a Fellow 